\title{
Consumers' Healthy Lifestyle: Does It Matter For The Consumption Pattern Of Healthy Food?
}

\author{
Farouk Djermani ${ }^{1}$, Yaty Sulaiman ${ }^{2}$, Nik Kamariah Nik Mat ${ }^{3}$, Muhammad Amsal \\ Sahban ${ }^{4}$ \\ ${ }^{1,2,3}$ Universiti Utara Malaysia \\ ${ }^{4}$ STIM Lasharan Jaya Makassar, Indonesia \\ frie.sein@gmail.com
}

\begin{tabular}{ll}
\hline \multicolumn{2}{l}{ ARTICLEDETAILS } \\
\hline History & : August \\
Received & Revised Format $:$ September \\
Accepted $\quad$ October \\
\hline
\end{tabular}

Keywords :

consumption patterns, healthy food, promotion, place and consumer healthy lifestyle.

\begin{abstract}
S
Unhealthy food consumption has been linked to the risk of many diseases such as non-communicable disease and obesity. The objective of this paper is to identify the influencing factors that determine the consumption patterns of healthy food among academician in the northern part of Malaysia and its causal relationships using a theoretical model based on the Stimuli's organism response theory. A quantitative research design approach was selected where the questionnaire was formulated for primary data collection Data were collected from 360 respondents in Malaysia by using systematic random sampling and subjected to Smart PLS analysis. The proposed model fits the data well by having good validity and reliability. The results revealed that the consumer healthy lifestyle fully mediated the relationship between promotion, place and the consumption pattern of healthy food. Finally, implications and recommendations of these findings are discussed.
\end{abstract}

\section{INTRODUCTION}

A healthy food which is primarily about dietary diversity consuming a variety of foods is essential to meet energy and nutrient requirements in our body. Consumption of a wide range of whole foods, especially vegetables, fruits, legumes, whole grains and nuts, is particularly essential (Bereuter \& Glickman, 2015).

According to Lee (2009) consumption patterns refers to the behaviour of individuals and households when they make decisions to consume the product using their available resources continuously. The lack of healthy food consumption has led to various NCD among Malaysian consumers. The National Health and Morbidity Survey (2015) found that NCDs have continuously become the main health problem in Malaysia (IPH, 2015).

Nowadays, a healthy diet is mainly a variety of consuming different foods groups get the important required nutrients and energy. Therefore, the consumption of broad different food groups, mainly vegetables, fruits, legumes, whole grains and nuts, is essential (Bereuter \& Glickman, 2015). The rapid growth of fast food industries. Several studies by Eves and Corney (1998), and Lee and Kim (2013) have defined healthy food as low fat, reduced sugar, high fibre, containing fruits and vegetables, and being prepared using appropriate cooking methods.

This study discusses a healthy lifestyle in two dimensions a natural food consumption and health care. Consequently, busy lifestyles have engendered unhealthy dietary habits that shifted from natural food consumption to unhealthy habits consumption (Chen, 2011). Kraft and Goodell (1993) pointed out that an unhealthy lifestyle is associated with a poor diet. 


\section{LITERATURE REVIEW}

\section{Consumers' Healthy Lifestyle and consumption patterns}

Divine and Lepisto (2005) defined a healthy lifestyle "as an orientation toward the prevention of health problems and the maximization of personal wellbeing. While this could legitimately encompass a wide variety of behaviors, most healthy lifestyle research has focused on diet and exercise" ( $p, 275)$. The importance of healthy food has been accepted in the food industry and among consumers, as they become more health aware and more interested in healthier lifestyles (Rafter, 2002). Consumption patterns of healthy food, healthy lifestyle are essential elements of the consumer for well-being and a healthy lifestyle.

The past empirical studies that investigated the direct relationship between consumer healthy lifestyle and consumption patterns (Andrews et al., 2017; Coomarasamy et al., 2014; Goetzke, Nitzko, \& Spiller, 2014). Overall, the findings a significant positive. For instance, Andrews et al. (2017) revealed a positive significant relationship between healthy dietary lifestyle and consumption patterns on fruit and vegetables. Coomarasamy, Wint, Neri, and Sukumaran (2014) discussed lifestyle influences on consumption patterns. Goetzke, Nitzko, and Spiller (2014) revealed that well-being is one of healthy lifestyle dimensions, was demonstrated a positive significant relationship with consumption patterns.

On the other hand, also past studies found insignificant association between the consumption patterns of healthy food and healthy lifestyle of the consumer (Goetzke et al., 2014; Jayaraman et al., 2013). For instance, Goetzke, Nitzko, and Spiller (2014) found that cognitive emotion and well-beings that are considered as determinant of healthy lifestyle, though cognitive emotion were not significant relationship to the consumption patterns. Jayaraman, Munira, Chowdhury, and Iranmanes (2013) found that a healthy concern is considered determinants of healthy lifestyle that was not significant to consumption patterns. Considering the above discussion, the researcher postulates the following hypotheses:

H1: Consumers' healthy lifestyle has a positive relationship with consumption patterns of healthy food.

\section{Place and consumer healthy lifestyle}

Includes issues such as distribution channels, market coverage, product inventory, transportation and distribution sites (Indumathi \& Dawood, 2016). Previous literature that found that place was one of the important factors of a healthy lifestyle (Borra \& Orgel, 2018; Jusoh \& Ahmat, 2017; Rakic \& Rakic 2015). For instance, Jusoh and Ahmet (2017) findings on environment regarded as place factor that showed significant relationship with healthy lifestyle among household of Malaysian consumers. Similarly, Rakic and Rakic (2015) found a significant positive relationship between place and healthy lifestyle. However, Borra \& Orgel, (2018) investigated conceptually, the impact of food retails on lifestyle. Considering the above discussion, the researcher postulates the following hypotheses:

\section{H2: Consumers' healthy lifestyle has a positive relationship with the place.}

\section{Place and consumption patterns}

Kearney (2010) revealed that practical changes in dietary patterns has significant impact on the consumption patterns of healthy food, particularly the rise in over nutrition. Alqurneh (2013) reported that convenient location increased the sale and consumption of organic products. Moreover, Krukowski et al., (2010) reveal that the availability of healthier foods likely has an impact on consumption; for instance, when greater store shelf space is devoted to products. The past studies, that showed a significant relationship between place with consumption patterns (Aggarwal et al., 2014; Al Kurdi, Barween \& Hikmat, 2016; Boniface \& Umberger, 2012). For example, Boniface and Umberger (2012) reported that convenient location, cleanliness of the store and availability of higher quality dairy products that are considered as a dimension of the place factor have the influence to increase the consumption of healthy food (organic products). 
On the contrary, Al Kurdi, Barween, and Hikmat (2016) did not find a significant influence of physical setting on consumption patterns of healthy food in the UK. However, they found a positive impact of social setting on consumption patterns. According Aggarwal, Cook, Jiao, Seguin, Moudon, Hurvitz, and Drewnowski (2014) to reported that physical distance to a supermarket is not associated with fruit and vegetable intake or overall diet quality. Aggarwal et al. (2014) reported in his findings that supermarket choice access has shown no effect on consumption patterns of fruit and vegetables among USA consumers. Based on the literature, the following hypotheses were developed as follows:

H3: Place has a significant positive relationship with the consumption patterns

\section{Promotion and consumer healthy lifestyle}

According to Duncan, promotion is an essential key for market exchange sales promotion, personal selling, public relations and direct marketing, which communicate the potential stakeholders (Borden, 1984). Indumathi and Dawood (2016) stated the sub-variables under promotion factor using free home delivery to encourage, using offer coupon to encourage, popularity of the organic store as a distinguished shop, using members' ideas and proposals, giving discounts to regular buyers. Several studies have found that promotion is positively related to consumption patterns. The past studies, that showed the significant relationship between promotion consumers` healthy lifestyle (Cheah et al., 2015; Rojas-Rajs \& Soto, 2013; Rakic \& Rakic 2015). For example, according to Cheah et al. (2015), noted the impact of the promotion of nutritional label food towards a healthy lifestyle. That showed a positive significant influence on healthy lifestyle towards Malaysian consumers. Rakic and Rakic (2015) pointed out the importance of different channel communication (e.g., word of mouth communications of families \& friends, word of mouth communications of consumers, communications of schools and universities, communications of government and non- profit organisations, media, advertising, sales promotion, and public relations) influenced positively on healthy lifestyle among 400 of Serbian consumers. For example, Rojas-Rajs \& Soto (2013) explored conceptually the impact of health communication of healthy lifestyle in American Latin. Considering the above discussion, the researcher postulates the following hypotheses:

H4: Consumers' healthy lifestyle has a positive relationship with promotion.

\section{Promotion and consumption patterns}

According to Gilbert (1999), price reduction, coupons or refunds given by retailers, other sales promotional tools such as free sampling and buy-one-get-one-free or in-pack premium item were found to be inducing consumers to purchase more of the product. As one of the main reasons according to Indumathi and Dawood (2016) promotion factors impacts the purchase decision of healthy food products were found that accessibility to healthy food and cheaper products influenced the consumption patterns of healthy food. The past studies that demonstrated the positive relationship between promotion and consumption pattern of healthy food (Indumathi \& Dawood, 2016; Irfan et al., 2014; Nguyen, Phan, \& Vu, 2015). According to Indumathi, and Dawood (2016) promotion factors impacts the purchase decision of healthy food product were found that accessibility to healthy food and cheaper products influenced the consumption patterns of healthy food. The research of Nguyen et al. (2015) also indicated that promotion has a positive significant role in influencing consumption patterns. This study confirmed the impact of the promotion on healthy food consumption patterns among the Amsterdam consumers. Irfan et al. (2014) concluded that promotion aims to increase consumption more frequently with great quantity. Irfan et al. (2014), observed that price promotions have a significant positive impact to increase consumption patterns of certain healthy food products. Based on the literature, the following hypotheses were developed as follows:

\section{H5: Promotion has a significant positive relationship with the consumption patterns}




\section{Consumers` Healthy Lifestyle Mediates Between Promotion and Consumption Patterns of Healthy Food}

The mediation effect of consumer healthy lifestyle on promotion and consumption patterns has been rarely discussed in past empirical research in healthy food (Blackwell et al 2006; Hawkins et al. 1998; Sulaiman et al. 2014). Under-review study conducted by Sulaiman et al.(2014), tested the mediation effect on consumer lifestyle in the link between promotion and consumption patterns among Malaysian consumers. Similarly, Hawkins et al. (1998), proposed a conceptual model to test the intervening variable of consumer lifestyle between promotion under marketing activities towards consumer decision process by referring to consumption patterns. Furthermore, Blackwell et al. (2006) investigated lifestyle as mediator role between marketing mix components such as promotion and decision-making process by referring to the consumption patterns in a conceptual model. Thus, most studies are under-review suggested a mediation effect of consumer lifestyle on marketing mix components towards consumption patterns.

Since there are few studies on the mediation of healthy lifestyle on promotion and consumption patterns the present study, was explore intervening variable effect between promotion towards the consumption patterns. Hence, the following hypothesis was formulated:

H6: Consumer healthy lifestyle mediates the relationship between promotion and consumption pattern of healthy food.

\section{Consumers` Healthy Lifestyle Mediates Between Place and Consumption Patterns of Healthy Food}

The mediation influence of consumer healthy lifestyle on promotion and consumption patterns has been rarely discussed in past empirical research in healthy food. (Blackwell et al.,2006; Chen, 2009; Hawkins et al., 1998; Sulaiman et al., 2014).

Hawkins et al. (1998) suggested a conceptual model with mediating role of consumer lifestyle effecting the link between marketing mix components such as place towards the consumer decision process by referring to the consumption patterns. Likewise, Blackwell et al. (2006) proposed a conceptually a model of the effect of lifestyle as mediator between the marketing efforts components such as place under external factors towards decision-making process by referring to consumption patterns. Sulaiman et al. (2014) proposed a conceptual model with intervening variable of consumer lifestyle in influence the link between place towards consumption patterns. Few past studies which investigated the mediation of healthy lifestyle in the link between place and consumption patterns, due to this the present study aims to investigate the mediating effect empirically; hence, the following hypothesis was formulated:

H7: Consumer healthy lifestyle mediates the relationship between place and consumption pattern of healthy food. 


\section{METHODOLOGY}

\section{Research framework}

Based on the discussion of variables in literature review section. The research framework presented in Figure 1

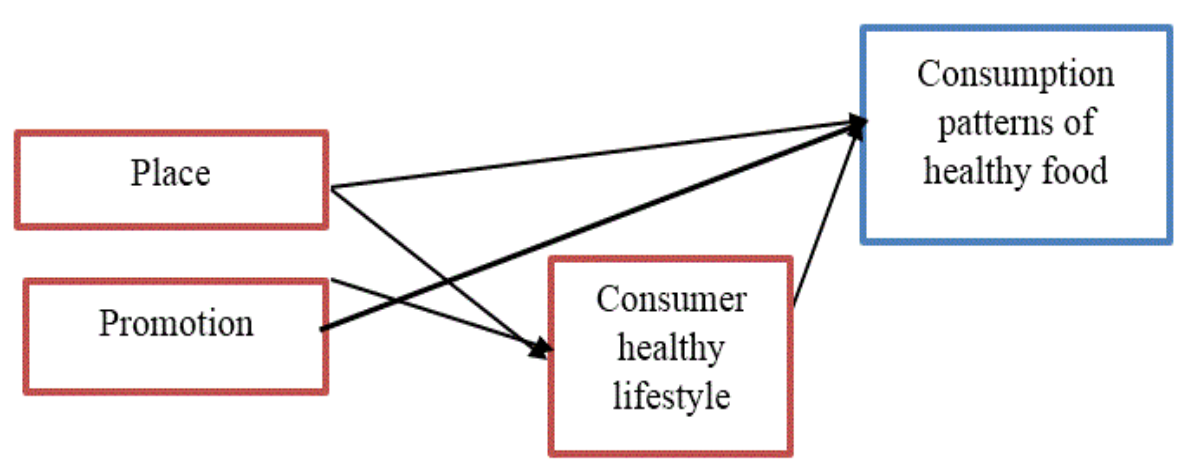

A quantitive approach used to answer the research questions in this study, a quantitative method was used. Specifically, after the data gathering, a preliminary data analysis was conducted by applying and presenting the demographic analysis regarding the research sample. Afterward, partial least squares-structural equation smart PLS 3 used for the advanced quantitative analysis, along with the revised research model and the research hypotheses. Details about each phase are presented in the subsequent sections.

In the current study, the questionnaire was distributed among the lecturers of higher education institutions of this study and includes Kedah, Perlis, Perak and Penang universities lecturers, assistant professors, associate professors and professors.

Data were collected using a systematic sampling approach self-administered survey. Participants were meant to be older than 25 years and all academic staff. The total population number of academics in the northern part of Malaysia is 4940 the sample size 357 (Krejcie \& Morgan, 1970). Thus, 500 questionnaires were distributed. In total, 357 respondents, yielding higher than $72 \%$, took the survey within a six-week period July up to September (2018). Respondents were invited to complete the survey setting.

The measurement of the variable consumption patterns on healthy general healthy food without any specification on different categories adapted from authors Salleh al., (2014). These authors also adapted the measurement from Lee (2009). Meanwhile the source of the consumerconsumption behavior measure for this study was based on a study of Lee (2009). The measurement items of promotion as independent variable adapted from (Indumathi \& Dawood, 2016). Using 5 Likert scale that ranges from "Strongly Disagree" (1) to "Strongly Agree" (5).

\section{FINDINGS AND DISCUSSION}

\section{Demographic Profile of Respondents}

Table 1 presents the demographic profile of the surveyed respondents. The total sample of this study was 360 respondents. respondent accounted for $49.2 \%$, while females comprised $58.8 \%$. The ages between 25 and 30 years old constituted $8.1 \%$ of the total respondents, $42 \%$ aged between $31-40$ years old, while another $16.7 \%$ whose age are more than 51 years old. Most of the participants was married (75.3\%) and Malay Muslim (81.7\%). Majority of the respondents passed the tertiary education. Table 1 also indicated that $36.7 \%$ of the participants serves as senior lecturers, while only $25.8 \%$ of them having more than 6 to 10 years of experience. In terms of their originality, the distribution between rural (30.0\%) and urban (69.7\%) was higher. 
Lastly, it was found that most of the participants earned more than RM 9,000 a month with $20.8 \%$.

Table 1

Demographic profile

\begin{tabular}{lcc}
\hline Demographic Constructs & Frequency & Percentage \\
\hline Gender & 177 & \\
Males & 183 & 49.2 \\
Females & & 50.8 \\
Age (years) & 29 & \\
25-30 years old & 153 & 8.1 \\
31-40 years old & 119 & 42.0 \\
41- 50 years old & 59 & 33.2 \\
51 years old and above & & 16.7 \\
Occupation & 107 & \\
Lecturer & 132 & 29.7 \\
Senior lecturer & 84 & 36.7 \\
Associate professor & 18 & 23.3 \\
Professor & 19 & 5.0 \\
Other position & & 5.3 \\
Region & 251 & \\
Urban & 109 & 69.7 \\
Rural & & 30.3 \\
Income & 39 & \\
Less than RM 5000 & 31 & 9.2 \\
RM 5001- RM 6000 & 69 & 8.6 \\
RM 6001- RM 7000 & 63 & 19.2 \\
RM 7001- RM 8000 & 48 & 17.5 \\
RM 8001-RM 9000 & 75 & 13.3 \\
Rm 9001 -RM 10000 & 41 & 13.3 \\
Over RM 10001 & & 11.4 \\
&
\end{tabular}

\section{Measurement Model}

In the measurement model is to assess their construct reliability, convergent validity and discriminant validity (Figure 1)

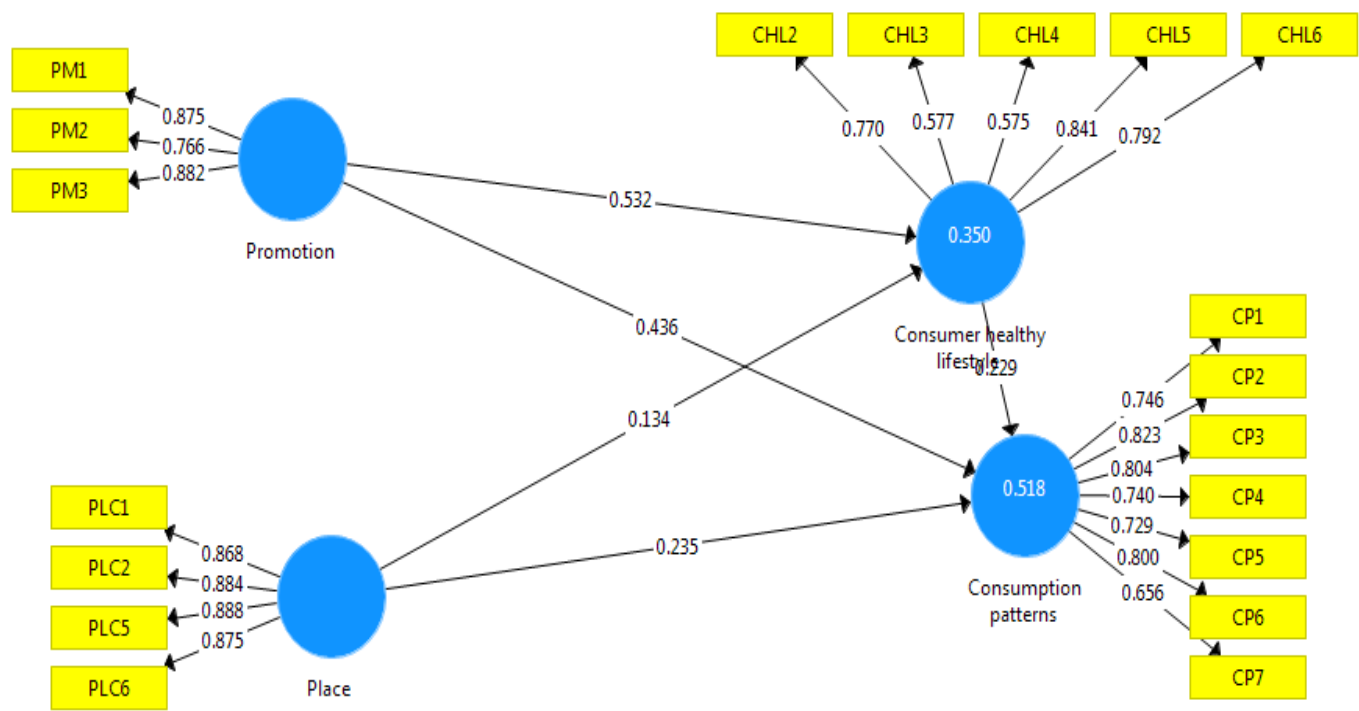

Figure 1

Measurement model 
As shown in Table 2, all the 24 items, and 19 items demonstrated acceptable loading factor that higher than 0.7, and 5 items (PM4(0.104), PM5(0.490), PLC4(0.045), PLC3(0.193), CHL1(0.365)) were deleted due to a low loading. Based on the analysis, most items in the measurement model exhibited loadings ranging from 0.575 to 0.888 . The Cronbach's alpha values ranged from 0.840 to 0.902 for four constructs that exceeded the 0.5 (Nunnally, 1978). The values indicated that the high internal consistency of measure reliability was in line with Nunnally and Bernstein (1994). Likewise, the composite reliabilities for all measures were high, ranging from 0.840 to 0.931 . To conclude, both the convergent and discriminant validity of the measures were established in this study. Further, the total items correlations for these constructs were examined. The correlation pattern indicated that every item had a stronger correlation with its construct than another construct. Moreover, the average variance extracted (AVE) also represented a value higher than 0.5 , and ranged from 0.518 to 0.772 , which is above the recommended threshold value of 0.5 (Barclay et al., 1995). In general, the results show that all the four constructs, namely promotion, place, consumer healthy lifestyle and consumption patterns has demonstrated good convergent validity.

Table 2

Results of the measurement model

\begin{tabular}{|c|c|c|c|c|c|c|}
\hline Constructs & Items & Loading & $\begin{array}{l}\text { Cronbach's } \\
\text { Alpha }\end{array}$ & $\begin{array}{l}\text { Composite } \\
\text { Reliability }\end{array}$ & (AVE) & $\begin{array}{l}\text { Deleted } \\
\text { item }\end{array}$ \\
\hline \multirow[t]{7}{*}{ Consumption patterns } & $\mathrm{CP} 1$ & 0.746 & 0.876 & 0.904 & 0.576 & \\
\hline & $\mathrm{CP} 2$ & 0.823 & & & & \\
\hline & $\mathrm{CP} 3$ & 0.804 & & & & \\
\hline & $\mathrm{CP} 4$ & 0.740 & & & & \\
\hline & $\mathrm{CP5}$ & 0.729 & & & & \\
\hline & CP6 & 0.800 & & & & \\
\hline & $\mathrm{CP} 7$ & 0.656 & & & & \\
\hline \multirow[t]{5}{*}{$\begin{array}{l}\text { Consume healthy } \\
\text { lifestyle }\end{array}$} & CHL2 & 0.770 & 0.769 & 0.840 & 0.518 & CHL1 \\
\hline & CHL3 & 0.577 & & & & \\
\hline & CHL4 & 0.575 & & & & \\
\hline & CHL5 & 0.841 & & & & \\
\hline & CHL6 & 0.792 & & & & \\
\hline \multirow[t]{4}{*}{ Place } & PLC1 & 0.868 & 0.902 & 0.931 & 0.772 & PLC3 \\
\hline & PLC2 & 0.884 & & & & \\
\hline & PLC5 & 0.888 & & & & \\
\hline & PLC6 & 0.875 & & & & \\
\hline \multirow[t]{3}{*}{ Promotion } & PM1 & 0.875 & 0.798 & 0.880 & 0.710 & PM4 \\
\hline & PM2 & 0.766 & & & & \\
\hline & PM3 & 0.882 & & & & \\
\hline
\end{tabular}

Table 3 depicted that the correlation between the variables is greater than the related interconstruct correlations in the construct correlation matrix, indicating adequate discriminant validity for all of the reflective constructs (Larcker, 1981). Therefore, the discriminant validity was established. 
Table 3

Table Fornell \& Larcker, 1981

\begin{tabular}{lcccc}
\hline Constructs & $\begin{array}{c}\text { Consumer } \\
\text { healthy } \\
\text { lifestyle }\end{array}$ & $\begin{array}{c}\text { Consumption } \\
\text { patterns }\end{array}$ & Place & Promotion \\
\hline Consumer healthy & & & & \\
lifestyle & $\mathbf{0 . 7 1 9}$ & & & \\
Consumption patterns & 0.557 & $\mathbf{0 . 7 5 9}$ & & \\
Place & 0.318 & 0.457 & $\mathbf{0 . 8 7 9}$ & $\mathbf{0 . 7 5 3}$ \\
Promotion & 0.579 & 0.683 & 0.498 & $\mathbf{0 . 7 5}$ \\
\hline
\end{tabular}

\section{Heterotrait- Monotrait (HTMT)}

In this study HTMT value should be less than 0.85 for conceptually distinct constructs and less than 0.9 for conceptually similar constructs.

Table 4

Heterotrait- Monotrait (HTMT)

\begin{tabular}{lllll}
\hline Constructs & $\begin{array}{l}\text { Consumer } \\
\text { healthy } \\
\text { lifestyle }\end{array}$ & $\begin{array}{l}\text { Consumption } \\
\text { patterns }\end{array}$ & Place & Promotion \\
\hline $\begin{array}{l}\text { Consumer healthy } \\
\text { lifestyle }\end{array}$ & & & \\
Consumption patterns & 0.615 & & \\
Place & 0.339 & 0.509 & \\
Promotion & 0.713 & 0.770 & 0.389 \\
\hline
\end{tabular}

\section{Structural Model}

Hair et al. (2014) suggested the results of the structural model were obtained by using the bootstrapping procedure with 500 times of resampling.

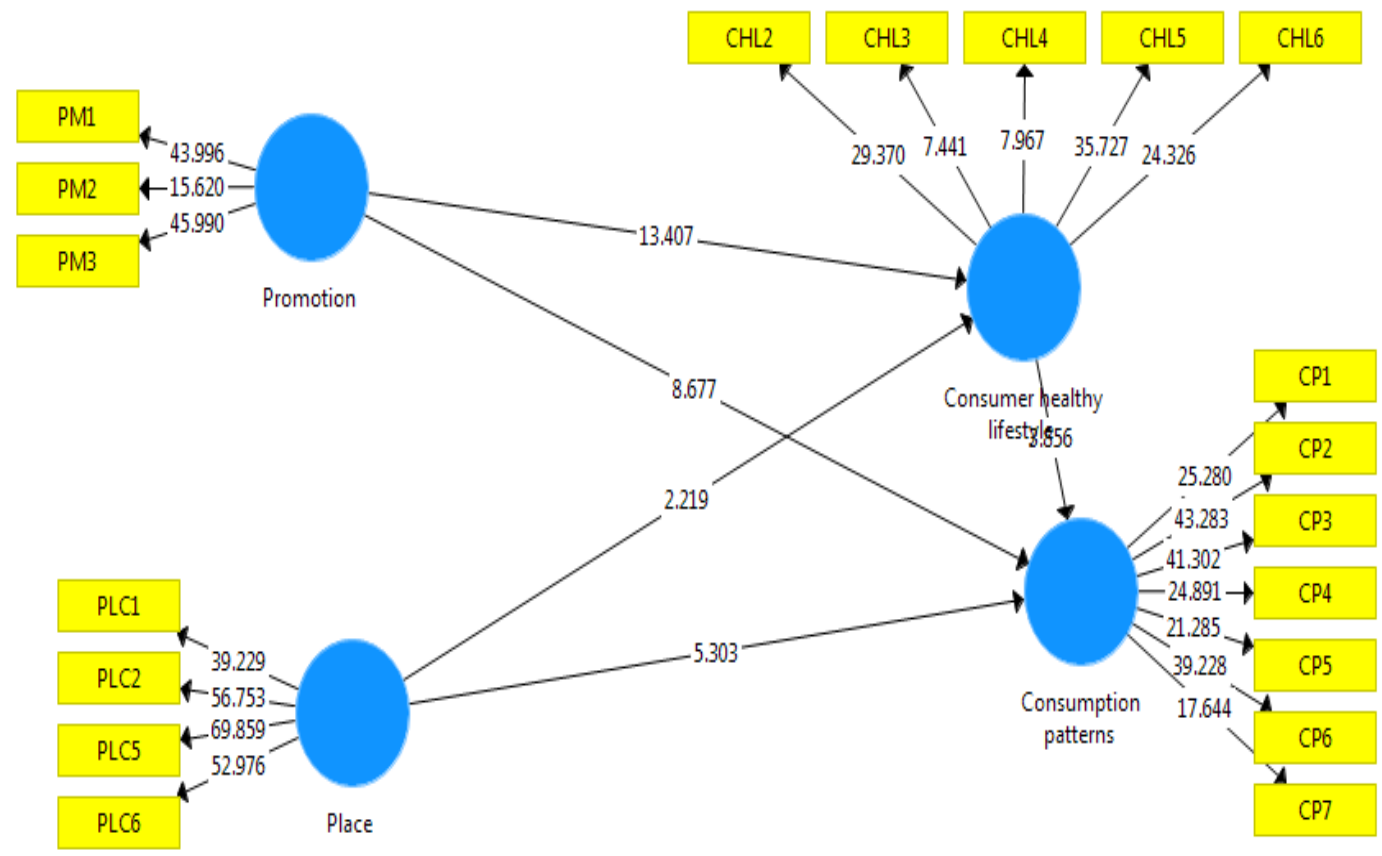

Figure 2

Structural model 


\section{Direct relationship}

Assessment of the hypothesis (path coefficients), by examining the standard error, T-statistics and confidence interval (Hair et al., 2014), as shown in Table 4 indicated that the five hypotheses (H1, H2, H3, H4 and H5) were supported.

Table 4

Hypothesis testing direct relationship

\begin{tabular}{|c|c|c|c|c|c|c|c|c|}
\hline HYP & Relationship & $\begin{array}{l}\text { B } \\
\text { value }\end{array}$ & $\begin{array}{l}\text { Std } \\
\text { error }\end{array}$ & $\begin{array}{l}T \\
\text { value }\end{array}$ & $\begin{array}{l}\mathbf{P} \\
\text { Values }\end{array}$ & Decision & $\mathbf{R 2}$ & F2 \\
\hline $\mathrm{H} 1$ & $\begin{array}{l}\text { Consumer } \\
\text { healthy lifestyle } \\
-> \\
\text { Consumption } \\
\text { patterns }\end{array}$ & 0.229 & 0.059 & 3.856 & 0.000 & Supported & 0.518 & 0.071 \\
\hline $\mathrm{H} 2$ & $\begin{array}{l}\text { Place -> } \\
\text { Consumer } \\
\text { healthy lifestyle }\end{array}$ & 0.134 & 0.060 & 2.219 & 0.027 & Supported & & \\
\hline $\mathrm{H} 3$ & $\begin{array}{l}\text { Place -> } \\
\text { Consumption } \\
\text { patterns }\end{array}$ & 0.235 & 0.044 & 5.303 & 0.000 & Supported & & 0.098 \\
\hline $\mathrm{H} 4$ & $\begin{array}{l}\text { Promotion -> } \\
\text { Consumer } \\
\text { healthy lifestyle }\end{array}$ & 0.532 & 0.040 & 13.407 & 0.000 & Supported & & \\
\hline H5 & $\begin{array}{l}\text { Promotion -> } \\
\text { Consumption } \\
\text { patterns }\end{array}$ & 0.436 & 0.050 & 8.677 & 0.000 & Supported & & 0.252 \\
\hline
\end{tabular}

Based on the analysis using Smart PLS 3, the results exposed that the consumption patterns are influenced by all driver factors, i.e. consume healthy lifestyle $(b=0.229, \mathrm{t}=3.856, \mathrm{p}<$ $0.001)$, place and consumer healthy lifestyle $(\mathrm{b}=0.039, \mathrm{t}=0.657, \mathrm{p}<0.001)$, place and consumption patterns $(b=0.235, t=5.303, p<0.001)$, promotion and consumer healthy lifestyle $(\mathrm{b}=0.532, \mathrm{t}=13.407, \mathrm{p}<0.001)$, and promotion and consumption patterns $(\mathrm{b}=0.436, \mathrm{t}=8.677, \mathrm{p}$ $<0.001)$.

The $\mathrm{R}^{2}$ value 51.8 per cent variations of consumption patterns are explained by the model consumer healthy lifestyle, promotion and place. The remaining 48.9 percent remains unexplained predictors, related to consumption patterns. The $\mathrm{R}^{2}$ value is above 0.26 , and according to Cohen (1988), indicates a substantial model.

The assessment of the effect sizes $\left(\mathrm{f}^{2}\right)$ according to Cohen (1988), values above 0.35, 0.15, and 0.02 are labelled as strong, moderate and weak. Table 4 showed the results of $\mathrm{f}^{2}$ in this study that all relationships were at "weak effect" for the H1 and H3, "medium effect" levels for H5.

\section{Indirect relationship}

Table 5 indicated the result of two indirect hypothesis, consumer lifestyle did not mediate between place and consumption patterns H6 $(b=0.009, t=0.574, p=0.566)$. Consumer healthy lifestyle did mediate between promotion and consumption patterns $\mathrm{H} 7(\mathrm{~b}=0.133, \mathrm{t}=4.273, \mathrm{p}=0.000)$ was supported. 
Table 5

\begin{tabular}{lllllll}
\multicolumn{2}{l}{ Indirect relationship hypothesizes } \\
\hline H & relationships & $\begin{array}{l}\text { B } \\
\text { value }\end{array}$ & $\begin{array}{l}\text { Standard } \\
\text { Deviation }\end{array}$ & $\begin{array}{l}\text { T } \\
\text { Statistics }\end{array}$ & P Value & Decision \\
\hline H6 & $\begin{array}{l}\text { Place -> Consumer healthy lifestyle } \\
\text {-> Consumption patterns }\end{array}$ & 0.031 & 0.018 & 1.710 & 0.088 & Not supported \\
H7 & $\begin{array}{l}\text { Promotion -> Consumer healthy } \\
\text { lifestyle -> Consumption patterns }\end{array}$ & 0.122 & 0.031 & 3.985 & 0.000 & supported \\
\hline
\end{tabular}

\section{LIMITATIONS AND RECOMMENDATIONS}

This study has a few methodological limitations that contribute in the following reasons. First, the sample size used in this study derived from one province. It can to extend this study to other parts of Malaysia, and to other underdeveloped countries as well as other industries. Second, this study was quantitative method; thus, future research it can focus on qualitative method. Another suggestion. Finally, other variables can have influence on consumption patterns with mediating role of consumers' healthy lifestyle.

\section{CONCLUSION}

The findings of this study can be generalized for Malaysia because it was conducted in the universities targeting lecturers. This model presented some important findings which could be applied for utilization in research on a bigger scale. This finding could include the whole of Malaysia, especially for those who actively involved in consumption patterns of food habits.

The main findings of this study that $36.5 \%$ of the respondents that represented by the senior lecturers aged between 30 to 40. Moreover, the majority of has income more than rm 6000 living in an urban area

\section{Promotion and Consumption Patterns}

The present study shows that the promotion factor is supported in consumption patterns. This finding is similar to past research that has shown a positive relationship between promotion and consumption patterns of healthy food (Indumathi \& Dawood, 2016)

The findings suggest that Food advertisements have a great effect on consumer's preferences, and it has been consistently have shown that food advertisements can increase purchase, and consumption of the brands' advertised (Irfan et al., 2014). Thus, this research study aims to enhance in the different numbers of the studies on healthy food to provide a model on consumption patterns that contribute on Malaysian consumers.

\section{Place and Consumption Patterns}

This research concludes that the place factor is supports to consumption patterns of healthy food. The finding is consistent with past studies that have shown a positively significant relationship between place and consumption pattern of healthy food(Aggarwal et al., 2014; Al Kurdi, Barween \& Hikmat, 2016; Boniface \& Umberger, 2012).

After reviewing the place factor items, Malaysian consumers tended to purchase healthy food from healthy food stores. The availability of healthy food stores nearby was found to increase the consumption of healthy food significantly. Also, stored with an appealing appearance and décor were found to increase the consumption of nutritious food (Boniface \& Umberger, 2012)

\section{Promotion and Consumer Healthy Lifestyle}

The study found that promotion was positively and significantly linked with a healthy lifestyle. The finding concurs with past studies (Cheah et al., 2015; Rojas-Rajs \& Soto, 2013; Rakic \& Rakic 2015). The result suggests that the popularity of healthy food stores that offer free home 
delivery significantly influences a healthy lifestyle. Current nutritional advances focus less on treatments and more on the role of nutrients, plant nutrients and other food ingredients in promoting health and preventing cancer, and heart disease, among other health concerns (Cheah et al., 2015).

\section{Place and Consumer Healthy Lifestyle}

The present study finds a significant influence of place on healthy lifestyle (Borra \& Orgel, 2018; Jusoh \& Ahmat, 2017; Rakic \& Rakic 2015). The result of this study that place has influence on consumer healthy lifestyle. May be one of the reasons that Malaysian consumers are relying in ordering healthy food via different communication tools that may shows that retails of healthy food stores have influence on healthy lifestyle behaviour. For instance, Jusoh and Ahmet, (2017) findings on environment regarded as place factor that showed significant relationship with healthy lifestyle among household of Malaysian consumers.

\section{The Mediating Effect of Consumer Healthy Lifestyle on the relationship between Promotion and Consumption Patterns of Healthy Food.}

The findings of this study provide support for the mediating of consumer healthy lifestyle role. More specifically, consumers healthy lifestyle underlies the relationship between promotion and consumption patterns. The result is consistent with past studies that found mediation of healthy lifestyle role (Blackwell et al., 2006; Hawkinks et al., 1998; Sulaiman., 2014).

Promotion leads to healthy lifestyle, which in turn leads to consumption patterns of healthy food. Because the lifestyle of the population is usually more hectic in urban than in rural areas (Hawkinks et al., 1998), the promotion of quality and healthy food products is likely to encourage Malaysian consumers to adopt a healthy, and hence change their consumption pattern to support such a lifestyle. Overall, this means that the consumers' positive consumption patterns of healthy food can be determined by promotion if the consumers are enthusiastic about undertaking a healthy lifestyle such as by eating natural food and taking health care of their health.

\section{The Mediating Effect of Consumers` Healthy Lifestyle on the relationship between Place and Consumption Patterns of Healthy Food for Malaysian Consumers.}

As indicated earlier in the results of this study, a healthy lifestyle does not mediate the relationship between place and consumption patterns of healthy food. The support for this finding is lacking (Sulaiman et al., 2014). The place is not perceived to be important by the respondents in this study, thus consumption patterns is not important to be boosted by place factor.

The finding suggests that the accessibility of malls and supermarkets in urban areas do not determine whether Malaysian consumers are healthy lifestyle supporters or otherwise. Since chain supermarkets and farmers' markets for Malaysian consumers in this study are not influencing to 4increase the consumption of healthy food, it can be difficult for residents to travel to locations where they can buy healthy foods like fruits and vegetables.

Therefore, the Malaysian consumers were not affected by the distance and availability of healthy food product store, or Malls market in their area, which is not significant to increase the consumption patterns towards healthy food. Thus, the online purchase and consumption of the product, the place as marketing components is becoming less significant to consumer. However, the significant of the promotion to the consumption seems is an essential approach in marketing that influence Malaysian consume to increase their consumption towards healthy food. Similarly, the change in the lifestyle on Malaysian consume were a crucial element to increase their consumption towards healthy food patterns. 


\section{REFERENCES}

Abdul Karim, N. H. (2010). The impact of work-related variables on librarians' organizational commitment and job satisfaction. Malaysian Journal of Library and Information Science, 15(3), 149-163. http://doi.org/10.6007/IJARBSS/v4-i2/562

Ackfeldt, A.-L., \& Coote, L. V. (2005). A study of organizational citizenship behaviors in a retail setting. Journal of Business Research, 58(2), 151-159. http://doi.org/10.1016/S0148-2963(03)00110-3

Aggarwal, A., Cook, A. J., Jiao, J., Seguin, R. A., Vernez Moudon, A., Hurvitz, P. M., \& Drewnowski, A. (2014). Access to supermarkets and fruit and vegetable consumption. American journal of public health, 104(5), 917-923.

Ajzen, I.: 1991, 'The Theory of Planned Behavior', Organizational Behavior \& Human Decision Processes 50, 179-211.

Ajzen, I. (2002). Perceived behavioral control, self-efficacy, locus of control, and the theory of planned behavior 1. Journal of applied social psychology, 32(4), 665-683.

Ali, N., \& Abdullah, M. (2012). The food consumption and eating behaviour of Malaysian urbanites issues and concerns. Malaysian Journal of Society and Space, 3(1), 44-53.

AL Kurdi, B. A. R. W. E. E. N. (2016). Healthy-food choice and purchasing behaviour analysis: An exploratory study of families in the UK (Doctoral dissertation, Durham University).

Andrews, H., Hill, T. D., \& Cockerham, W. C. (2017). Educational attainment and dietary lifestyles. Food Systems and Health: Emerald Publishing Limited, 101-20. https://doi.org/10.1108/S1057-629020170000018005

Blackwell, R. D., Miniard, P. W., \& Engel, J. F. (2006). Consumer Behavior (10th ed.). Mason, $\mathrm{OH}$ : Thomson South-Western.

Bereuter, D., \& Glickman, D. (2015). Healthy food for a healthy world: leveraging agriculture and food to improve global nutrition. United States of America. Retrieved from http://www.thechicagocouncil.org/publication/healthy-food-healthy-world.

Bloch, P. H., \& Bruce, G. D. (1984). Product involvement as leisure behavior. ACR North American Advances.

Boniface, B., \& Umberger, W. J. (2012). Factors influencing Malaysian consumers' consumption of dairy products (No. 423-2016-27006).

Borra, S., \& Orgel, D. (2018). Power of health and well-being in food retail (pp. 24-31). https://www.oliverwyman.com/content/dam/oliver-

wyman/v2/publications/2019/January/Boardroom-Vol4/Power of Health and Wellness_web.pdf

Borden, Neil. H. (1984) The concept of marketing mix, Journal of Advertising Research, 1 (9), $2-7$

Boulanger, P.-M. (2007). Sustainable consumption: a general framework for transition management. Retrieved from http://consentsus-project.pbworks.com/f/SustainableConsumption_BOULANGER.pdf

Bruns $\varnothing$ K, Grunert KG. Development and testing of a cross-culturally valid instrument: foodrelated lifestyle. In: Kardes F, Sujan M, editors. Ad- vances in consumer research, vol. 22. Provo (UT): Association for Consumer Research, 1995. pp. 475-80

Campbell, M. C. (1999). PRICING STRATEGY \& PRACTICE“Why did you do that?" The important role of inferred motive in perceptions of price fairness. Journal of Product \& Brand Management, 8(MARCH 1999), 145-153. http://doi.org/10.1108/10610429910266995 
Castellari, E. (2016). Three Essays on Food Policy and Health Consumption Patterns. Rivista Di Economia Agraria, 1(0035-6190). http://doi.org/10.13128/REA-18672

Chakma, J. K., \& Gupta, S. (2017). Lifestyle practice and associated risk factors of noncommunicable diseases among the students of Delhi University. International Journal of Health \& Allied Sciences, 6(1), 20.

Chang, Y., Polonsky, M. J., \& Junek, O. (2007). A preliminary examination of Berry, Seiders and Grewal's (2002) five-dimensional measure of convenience in a service setting. ANZMAC. of Otago, School of Business.

Cheah, Y. K., Moy, F. M., \& Loh, D. A. (2015). Socio-demographic and lifestyle factors associated with nutrition label use among Malaysian adults. British Food Journal, 117(11), 2777-2787.

Chen, M. F. (2009). Attitude toward organic foods among Taiwanese as related to health consciousness, environmental attitudes, and the mediating effects of a healthy lifestyle. British Food Journal, 111(2), 165-178.

Chin, W. W. 1998. "The Partial Least Squares Approach to Structural Equation Modeling," in Modern Methods for Business Research , G. A. Marcoulides (ed.), London: Psychology Press,pp. 295-336.

Cohen, J. (1988). Set correlation and contingency tables. Applied Psychological Measurement, 12(4), 425-434.

Cohen, J. (1988). Statistical power analysis for the behavioral sciences. Second

Edition. Hillsdale, NJ: Lawrence Erlbaum Associates, Publishers.

Cohen, J. (1988). Statistical power analysis for the behavioral sciences (2nd ed.). Hillsdale, NJ: Erlbaum.

Cornwell, T. B., Weeks, C. S., \& Roy, D. P. (2005). Sponsorship-linked marketing: Opening the black box. Journal of advertising, 34(2), 21-42.

Divine, R. L., \& Lepisto, L. (2005). Analysis of the healthy lifestyle consumer. Journal of Consumer marketing, 22(5), 275-283.

Ekinci, Y., Sirakaya-Turk, E., \& Preciado, S. (2013). Symbolic consumption of tourism destination brands. Journal of Business Research, 66(6), 711-718. http://doi.org/10.1016/j.jbusres.2011.09.008

Etikan, I., Musa, S. A., \& Alkassim, R. S. (2016). Comparison of convenience sampling and purposive sampling. American Journal of Theoretical and Applied Statistics, 5(1), 1-4. http://doi.org/10.11648/j.ajtas.20160501.11

Eves, Michael Corney, M. K. (1998). Nutrition knowledge of caterers and constraints to offering more healthy food meals. International Journal of Hospitality Management, 16(4), 403-417.

Fornell, C., \& Larcker, D. F. (1981). Evaluating structural equation models with unobservable variables and measurement error. Journal of marketing research, 18(1), 39-50.

Indumathi, N., \& Dawood, D. (2016). Impact of marketing mix on consumer buying behavior in organic. International Journal of Research in Finance and Marketing, 6(10), 43-54.

Ingram, D. M., Nottage, E., \& Roberts, T. (1991). The role of diet in the development of breast cancer: a case-control study of patients with breast cancer, benign epithelial hyperplasia and fibrocystic disease of the breast. British Journal of Cancer, 64(1), 187-191. http://doi.org/10.1038/bjc.1991.268.

Kearney, J. (2010). Food consumption trends and drivers. Philosophical transactions of the royal society B: biological sciences, 365(1554), 2793-2807.

Khan, M. S., Khan, I., Kundi, G. M., Khan, S., Nawaz, A., Khan, F., \& Yar, N. B. (2014). The 
Impact of Job Satisfaction and Organizational commitment on the Intention to leave among the Academicians. International Journal of Academic Research in Business and Social Sciences, 4(2), 114.

Kim, M., Lee, C., Gon Kim, W., \& Kim, J. (2013). Relationships between lifestyle of health and sustainability and healthy food choices for seniors. International Journal of Contemporary Hospitality Management, 25(4), 558-576. http://doi.org/10.1108/09596111311322925

Krejcie, R. V, \& Morgan, D. W. (1970). Determining sample size for research activities obert. Educational and Psychological Measurement, 38(1), 607-610. http://doi.org/10.1177/001316447003000308

Hair Jr, J. F., Hult, G. T. M., Ringle, C., \& Sarstedt, M. (2016). A primer on partial least squares structural equation modeling (PLS-SEM). Sage Publications.

Hair, J. F., Ringle, C. M., \& Sarstedt, M. (2011). PLS-SEM: Indeed a silver bullet. Journal of Marketing theory and Practice, 19(2), 139-152.

Hair Jr, F. J., Sarstedt, M., Hopkins, L., \& G. Kuppelwieser, V. (2014). Partial least squares structural equation modeling (PLS-SEM) An emerging tool in business research. European Business Review, 26(2), 106-121.

Hawkins, D. I., Mothersbaugh, D. L., \& Best, R. J. (1998). Consumer Behavior: Building Marketing Strategy 10/e. McGraw-Hill

Henseler, J., Hubona, G., \& Ray, P. A. (2016). Using PLS path modeling in new technology research: updated guidelines. Industrial management \& data systems, 116(1), 2-20.

Henseler, J., Dijkstra, T. K., Sarstedt, M., Ringle, C. M., Diamantopoulos, A., Straub, D. W., ... \& Calantone, R. J. (2014). Common beliefs and reality about PLS: Comments on Rönkkö and Evermann (2013). Organizational Research Methods, 17(2), 182-209.

Hong, R. Y., \& Paunonen, S. V. (2009). Personality traits and health-risk behaviours in university students. European Journal of Personality: Published for the European Association of Personality Psychology, 23(8), 675-696.

Hu, L. T., \& Bentler, P. M. (1998). Fit indices in covariance structure modeling: Sensitivity to underparameterized model misspecification. Psychological methods, 3(4), 424.

Irfan, M., Sabir, R. I., Lodhi, R. N., \& Mukhtar, A. (2014). Impact of Food Branding on Consumption Pattern of Children. Social and basic sciences research reviews, 1 (2), 118129.

Goetzke, B., Nitzko, S., \& Spiller, A. (2014). Consumption of organic and functional food. A matter of well-being and health? Appetite, 77, 94-103. https://doi.org/10.1016/j.appet.2014.02.012

Grunert, K. G., Nissen, L. \& Wildenhoff, L. Do Danish Food Companies Analyse their Competitors, February 1993.

Fishbein, M., \& Ajzen, I. (1975). Belief, attitude, intention and behavior: An introduction to theory and research.

Jusoh, Z. M., \& Ahmat, N. (2017). Willingness to Pay for the Consumption of Green Food Product among Households. Malaysian Journal of Consumer and Family Economics, December (20), 184-195.

Lee, K. (2009). Gender differences in Hong Kong adolescent consumers' green purchasing behavior. Journal of Consumer Marketing, 26(2), 87-96. http://doi.org/10.1108/07363760910940456

Nguyen, T. N., Phan, T. T. H., \& Vu, P. A. (2015). The impact of marketing mix elements on food buying behavior: a study of supermarket consumers in Vietnam. International Journal of Business and Management, 10(10), 206. 
Rakic, B. R., \& Rakic, M. R. (2015). The influence of integrated marketing communications on the process of creating a healthy lifestyle. Revista Romana de Bioetica, 13(3), 1-15.

Rafter, J. J. (2002). Scientific basis of biomarkers and benefits of functional foods for reduction of disease risk: cancer. British Journal of Nutrition, 88(S2), S219-S224.

Rajasekar, S., Philominathan, P., \& Chinnathambi, V. (2006). Research Methodology, 1-53. http://doi.org/arXiv:physics/0601009v3

Scholderer, J., Brunso, K., \& Grunert, K. G. (2002). Means-End Theory of lifestyle. Replication in the Uk. ACR North American Advances.

Sulaiman, Y., Mat, N. K. N., \& Ghani, N. H. A. (2014). Constructing a Consumption Model for Malaysian Consumers. Journal of Marketing Management, 2(3), 49-60. 